\title{
Chemo-Enzymatic Synthesis of a Multi-Useful Chiral Building Block Molecule for the Synthesis of Medicinal Compounds
}

\author{
Toshiki Nakano $^{1}$, Yusuke Yagi $^{2}$, Mizuki Miyahara ${ }^{2}$, Akio Kaminura ${ }^{1}{ }^{*}$, Motoi Kawatsura ${ }^{2}$ \\ and Toshiyuki Itoh ${ }^{2} *$
}

1 Department of Applied Molecular Bioscience, Graduate School of Medicine, Yamaguchi University, 2-16-1 Tokiwadai, Ube 755-8611, Japan

2 Department of Chemistry and Biotechnology, Graduate School of Engineering, Tottori University, 4-101 Koyama-minami, Tottori 680-8552, Japan

* Authors to whom correspondence should be addressed; E-Mails: ak10@ yamaguchi-u.ac.jp (A.K.); titoh@chem.tottori-u.ac.jp (T.I.); Tel.: +81-857-31-5259; Fax: +81-857-31-5259.

Received: 4 July 2011; in revised form: 2 August 2011 / Accepted: 4 August 2011 /

Published: 9 August 2011

\begin{abstract}
Optical resolution of 2-methyl-2-nitrobut-3-en-1-ol has been accomplished using a "low-temperature lipase-catalyzed transesterification" carried out at $-40{ }^{\circ} \mathrm{C}$.
\end{abstract}

Keywords: nitro alcohol; quaternary chiral carbon; lipase; optically active; synthesis

\section{Introduction}

Chemo-enzymatic reaction protocols are now well recognized as a very useful means to prepare optically active compounds [1-3]. 2-Methyl-2-nitrobut-3-en-1-ol $( \pm \mathbf{1})$ was prepared by a simple method using the nitroaldol reaction for nitroalkenes [4], and it has been expected to become a useful building block for the synthesis of various types of non-natural amino acids (A $\sim$ E) or amino alcohols $(\mathrm{F})$, as illustrated in Scheme 1. However, no one has yet succeeded in preparing optically pure nitro alcohol $\mathbf{1}$, so preparation of optically active $\mathbf{1}$ using a practical protocol has thus been strongly desired.

Lipases have wide applicability for various types of substrates [1-3,5], however, it is generally not easy to use the lipase-mediated reaction for the kinetic resolution of a primary alcohol like alcohol $\mathbf{1}$, because the chiral carbon is remote from the reaction point in such a type of compound [2]. Since preparation of chiral compounds that have a quaternary stereocenter is an important challenge for modern organic synthesis, several examples have been demonstrated using enzymatic reactions [6-13]. 
Herein, we report the establishment of a protocol that affords both enantiomers of 2-methyl-2-nitrobut3-en-1-ol (1) using a lipase-catalyzed reaction; the "low-temperature lipase-catalyzed reaction" protocol [14-16] was shown to be the key technology to accomplish the desired reaction with sufficient enantioselectivity.

Scheme 1. Multi-useful chiral building block for the synthesis of non natural amino acids and amino alcohols.

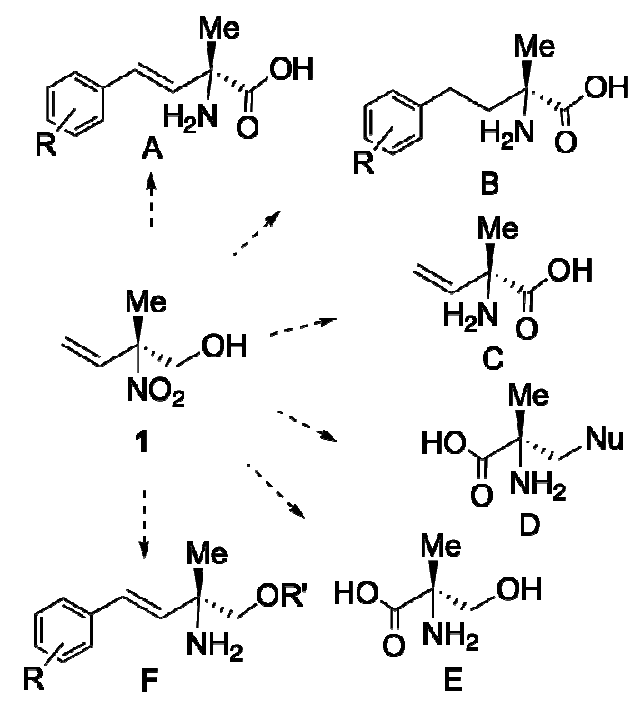

\section{Results and Discussion}

We initially attempted to resolve ( \pm )-1 via lipase-catalyzed transesterification using vinyl acetate as acyl donor in diisopropyl ether $\left(i\right.$ - $\left.\mathrm{Pr}_{2} \mathrm{O}\right)$ under standard reaction temperature at $35{ }^{\circ} \mathrm{C}$ (Scheme 2); however, after evaluating commercial lipases, we soon recognized that it would be a very tough task for us to find a suitable enzyme, as we were unsuccessful in finding an appropriate enzyme that could convert 1 to the corresponding acetate with acceptable enantioselectivity. Among the 17 types of commercial enzymes tested, only five lipases PS, SL-25, PL, Novozyme 435 and QLM gave the corresponding acetate, but all with insufficient enantioselectivity. Although lipases QLM and SL-25 gave somewhat better results, the E values [17] of the reactions were 7.2 (QLM) and 6.0 (SL-25), respectively. Since lipase QLM gave the best E value, we next attempted to optimize the reaction condition using lipase QLM as a catalyst.

Scheme 2. Kinetic resolution of ( \pm )-1 using an enzymatic reaction.

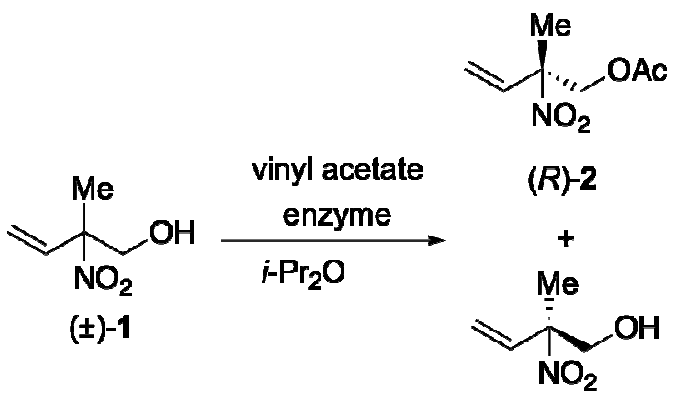

(S)-1 
It has long been believed that enantioselectivity of lipase-catalyzed reaction could be explained by the traditional three point attachment rule $[2,18]$. According to this rule, optimization of a substrate structure or protein engineering of lipases might be essential to control the enantioselectivity of the enzymatic reactions [2].

On the other hand, Ema et al. proposed that the enantioselectivity of the lipase-catalyzed reaction might be determined mainly by kinetic preference due to the conformational requirements and repulsive interaction on the transition state [19,20]. The model allows enhancement of the enantioselectivity of lipase-catalyzed reaction simply by changing the reaction temperature. Sakai and co-workers, in fact, demonstrated that efficient kinetic resolution of primary alcohols was realized using the "low-temperature transesterification method" [14-16]. Sakai showed that lipase-catalyzed transesterification of (2,2-dimethyl-1,3-dioxolan-4-yl)methanol in $i$ - $\operatorname{Pr}_{2} \mathrm{O}$ proceeded even at $-40{ }^{\circ} \mathrm{C}$; the $\mathrm{E}$ value of the reaction at $30^{\circ} \mathrm{C}$ was just 9, while it reached 55 when the reaction was conducted at $-40{ }^{\circ} \mathrm{C}[16]$. Therefore we decided to apply "the low-temperature method" to our lipase-catalyzed reaction (Scheme 1, and the results are summarized in Table 1).

Table 1. Results of lipase QLM-catalyzed transesterification of ( \pm )-1.

\begin{tabular}{ccccccc}
\hline Entry & Temp & Time & $\begin{array}{c}\text { \% ee of acetate } \\
(\boldsymbol{R})-\mathbf{2}^{\mathbf{a}}(\boldsymbol{\%} \text { yield })\end{array}$ & $\begin{array}{c}\text { \% ee of alcohol } \\
(\boldsymbol{S})-\mathbf{1}^{\mathbf{b}}(\boldsymbol{\%} \text { yield })\end{array}$ & $\boldsymbol{\%}_{\text {conv. }}$ & E value $^{\mathbf{c}}$ \\
\hline 1 & 35 & $10 \mathrm{~min}$. & $54(35)$ & $75(28)$ & 58 & 7.2 \\
2 & 20 & $25 \mathrm{~min}$. & $66(24)$ & $35(53)$ & 35 & 6.8 \\
3 & 0 & $25 \mathrm{~min}$. & $67(37)$ & $42(50)$ & 39 & 7.6 \\
4 & -20 & $30 \mathrm{~min}$. & $76(21)$ & $24(53)$ & 24 & 9.3 \\
5 & -40 & $25 \mathrm{~min}$. & $83(22)$ & $32(69)$ & 28 & 15 \\
6 & -40 & $26 \mathrm{~h}$ & $58(44)$ & $94(27)$ & 64 & 13 \\
\hline
\end{tabular}

${ }^{a}$ Determined by HPLC analysis using CHIRALCEL OB-H, hexane $/ i-\mathrm{PrOH}=19 / 1,0.5 \mathrm{~mL} / \mathrm{min}$;

${ }^{\mathrm{b}}$ Determined by HPLC analysis using CHIRALCEL AD-H, hexane $/ i-\mathrm{PrOH}=19 / 1,0.5 \mathrm{~mL} / \mathrm{min}$.

${ }^{\mathrm{c}} \mathrm{E}$ value was calculated by $\% e e$ of $(R)-2\left(e e_{p}\right)$ and \% ee of $(S)-\mathbf{1}\left(e e_{s}\right) \cdot \mathrm{E}=\ln \left[\left(1-\mathrm{c}\left(1+e e_{p}\right)\right) /\right.$ $\ln \left[\left(1-\mathrm{c}\left(1-e e_{p}\right)\right)\right.$; here, $\mathrm{c}$ means conv. which was calculated by the following formula according to reference [17]: $\mathrm{c}=e e_{s} /\left(e e_{p}+e e_{s}\right)$.

Lipase QLM-catalyzed transesterification of $( \pm)-\mathbf{1}$ proceeded very rapidly, and we obtained acetate $(R)-2$ in $35 \%$ yield with $54 \%$ ee, and unreacted alcohol $(S)-1$ was recovered from the reaction mixture in $28 \%$ yield with $75 \%$ ee after just 10 min of reaction (entry 1). Enantiomeric excess of the product and unreacted substrate were determined by HPLC analysis using a chiral column. A slightly enhanced enantioselectivity was recorded when the reaction was carried out at $-20{ }^{\circ} \mathrm{C}$ (entry 4), and it finally reached $\mathrm{E}=15$ at $-40{ }^{\circ} \mathrm{C}$ (entry 5). Since the reaction rate was very fast, we obtained $(R)-2$ with $83 \%$ $e e$ when the reaction was stopped at 25 min (entry 5), while $94 \%$ ee of $(S)-1$ was obtained after $26 \mathrm{~h}$ of reactions (entry 6); no improved enantioselectivity was recorded when the reaction was conducted at $-60{ }^{\circ} \mathrm{C}$. Based on the results, we have developed a protocol providing $(R)-\mathbf{2}$ and $(S)-\mathbf{1}$ with high enantiomeric purities as illustrated in Scheme 3. 
Scheme 3. Protocol of preparation of chiral 1 using "low-temperature lipase-catalyzed transesterification".

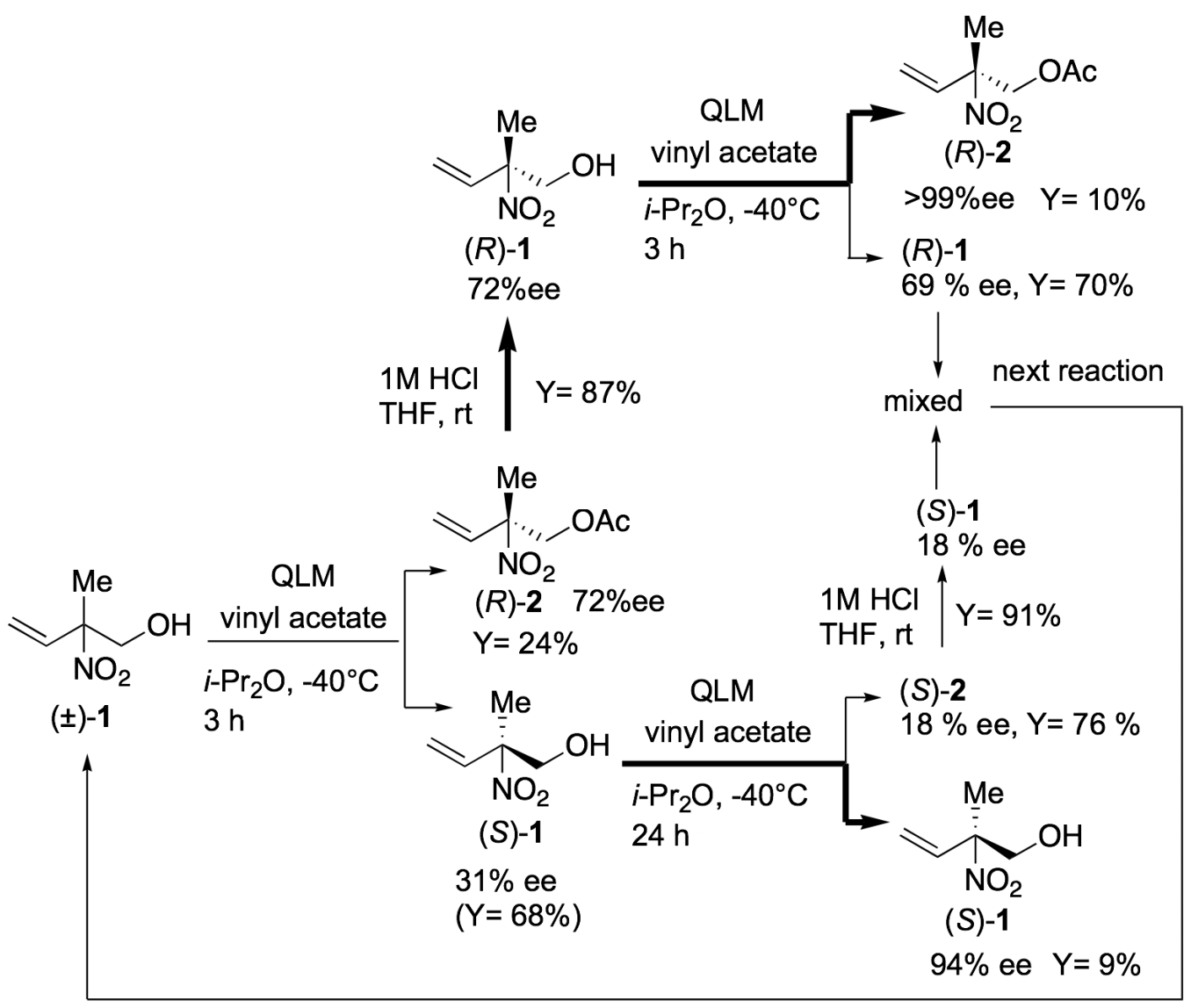

Racemic ( \pm )-1 was subjected to lipase-QLM-catalyzed transesterification at $-40{ }^{\circ} \mathrm{C}$, after being stirred for $3 \mathrm{~h}$, the reaction was stopped and the acetate $(R)-\mathbf{2}(72 \% e e)$ and alcohol $(S)-\mathbf{1}(31 \% e e)$ were separated. Enantiomeric purities of $(R)-\mathbf{2}$ and $(S)-\mathbf{1}$ were not sufficient at this stage, so $(R)-2$ was converted to $(R)-\mathbf{1}$ by acid hydrolysis in $87 \%$ yield without any loss of the optical purity. The resulting $72 \%$ ee of alcohol $(R)-1$ was subjected to a second transesterification. After $3 \mathrm{~h}$ reaction, optically pure $(R)$-2 ( $>99 \%$ ee) was obtained in $10 \%$ yield (the upper route in Scheme 3). (S)-1 (31\% ee) was subjected to a second reaction for $24 \mathrm{~h}$ and $94 \%$ ee of $(S)-1$ was obtained in $9 \%$ yield (the bottom route in Scheme 3). Although the chemical yield of each reaction was insufficient, this protocol made it possible to provide $(R)-\mathbf{2}$ and $(S)$-1 with high optical purity. After repeating the process, we succeeded in obtaining multiple grams of $(R)-2$ and $(S)-1$ with excellent optical purity (Scheme 3 ).

Development of efficient means for preparing chiral compounds that have a quaternary chiral center has been a challenging area in the field of synthetic organic chemistry. In particular, it is difficult to achieve this aim by enzymatic reaction because hydrolytic enzymes are usually unable to accept sterically hindered substrates bearing fully substituted quaternary carbons [2]. It should be emphasized that the present "low-temperature lipase-catalyzed reaction" provides a possible solution to this problem. 


\section{Experimental}

\subsection{General Procedures}

Reagents and solvents were purchased from common commercial sources and used as received or purified by distillation over appropriate drying agents. Reactions requiring anhydrous conditions were carried out under dry argon, freshly distilled solvents, and magnetic stirring. We tested the following commercial lipases: Lipase QL and QLM (Alcaligenes sp., Meito), Lipase SL and SL-25 (Burlholderia cepacia, Meito), Novozyme 435 (Candida antarctica, NOVO), Lipase OF (Candida rugosa lipase, Meito), Lipase PS (Burlholderia cepacia, Amano), Lipase AL (Acromobacter sp., Meito), Lipase PL (Alcaligenes sp, Meito), Lipase A (Aspergillus niger, Amano), Lipase AK (Pseudomonas fluorescens, Amano), Lipase D (Actinomadura sp., Meito), Lipase MY (Candida cylindracea, Amano), Lipase F-AP15 (Rhizopus oryzae, Amano), Lipase AY (Pseudomonas fluorescence), Lipase TL (Pseudomonas stutzeri, Amano), and PPL (Porcine pancreatin lipase, Sigma). Thin layer chromatography was performed with the indicated solvents and Wako gel B-5F. ${ }^{1} \mathrm{H}-\mathrm{NMR}$ spectra was recorded on JEOL (500 MHz). ${ }^{13} \mathrm{C}$-NMR spectra was recorded on JEOL $(125,100 \mathrm{MHz})$. Chemical shifts are expressed in ppm downfield from tetramethylsilane (TMS) in $\mathrm{CDCl}_{3}$ as an internal reference. Optical rotation was measured with a JASCO DIP-370 digital polarimeter. The optical purity was determined by HPLC analysis using CHIRALCEL OB-H and AD-H (Daicel).

\subsection{Preparation of 2-methyl-2-nitrobut-3-en-1-ol ( $\pm \mathbf{1})$ (Scheme 4) [4]}

Nitroethane (22.6 g, $301 \mathrm{mmol})$ was reacted with acetaldehyde $(25.5 \mathrm{~mL}, 451 \mathrm{~mol})$ in the presence of 1,8-diazabicyclo[5.4.0] undec-7-ene (DBU) $(2.0 \mathrm{~mL}, 13.3 \mathrm{mmol})$ at $0{ }^{\circ} \mathrm{C}$ and the mixture was stirred for $2 \mathrm{~h}$ at $\mathrm{rt}$. The reaction was quenched by addition of $10 \mathrm{~mL}$ of $1 \mathrm{M} \mathrm{HCl}$ aqueous solution and $100 \mathrm{~mL}$ of diethyl ether, then the organic layer was washed with $1 \mathrm{M} \mathrm{HCl}$ (3 times) and brine (3 times) and dried over $\mathrm{MgSO}_{4}$. After evaporation, Kugelrohr distillation of the resulting oil gave 3-nitrobut-2-ol (3) $(9.24 \mathrm{~g}, 77.6 \mathrm{mmol})$ in $26 \%$ yield. Nitroalcohol $3(9.24 \mathrm{~g}, 77.6 \mathrm{mmol})$ was treated with acetic anhydride $(7.8 \mathrm{~mL}, 82.5 \mathrm{mmol})$ in the presence of 5 drops of concd. sulfuric acid and the mixture was stirred at $\mathrm{rt}$ for $4 \mathrm{~h}$. To this mixture was added $100 \mathrm{~mL}$ of diethyl ether and the resulting organic layer was washed with brine ( 5 times) and dried over $\mathrm{NaSO}_{4}$. After removal of the solvent by evaporation, the resulting oily product was mixed with sodium acetate $(6.49 \mathrm{~g}, 79.1 \mathrm{mmol})$ and the acetate removed under reduced pressure at 1.0 Torr at $100{ }^{\circ} \mathrm{C}$. After being cooled to $\mathrm{rt}$, the resulting product was diluted with hexane $(100 \mathrm{~mL})$ and the organic layer was washed with water (3 times) and dried over $\mathrm{NaSO}_{4}$. Kugelrohr distillation gave 2-nitrobut-2-ene (4) (3.11 g, $30.8 \mathrm{mmol})$ in $40 \%$ yield. To an acetonitrile $(100 \mathrm{~mL})$ solution of $4(1.10 \mathrm{mg}, 10 \mathrm{mmol})$ was added formaldehyde $(1.41 \mathrm{~g}, 16.4 \mathrm{mmol})$ and 1,4-diazabicyclo[2.2.2] octane (DABCO) $(150 \mathrm{mg}, 1.3 \mathrm{mmol})$ and the mixture was stirred at $\mathrm{rt}$ for $24 \mathrm{~h}$, then $1 \mathrm{M} \mathrm{HCl}(10 \mathrm{~mL})$ and water $(50 \mathrm{~mL})$ were added. The mixture was extracted with ethyl acetate and the combined organic layer was washed with brine (3 times) and dried over $\mathrm{NaSO}_{4}$; evaporation and silica gel flash column chromatography (hexane: ethyl acetate $=10: 1$ to $5: 1$ ) then afforded ( \pm -1 $(1.00 \mathrm{~g}, 8.30 \mathrm{mmol})$ in $76 \%$ yield. ${ }^{1} \mathrm{H}-\mathrm{NMR}\left(500 \mathrm{MHz}, \delta, \mathrm{CDCl}_{3}\right): 6.17-6.11(1 \mathrm{H}, \mathrm{dd}, J=17.1 \mathrm{~Hz}$, $6.3 \mathrm{~Hz}), 5.49(1 \mathrm{H}, \mathrm{d}, J=17.1 \mathrm{~Hz}), 5.43(1 \mathrm{H}, \mathrm{d}, J=6.3 \mathrm{~Hz}), 4.12-4.09(1 \mathrm{H}, \mathrm{m}), 3.82-3.80(1 \mathrm{H}, \mathrm{m})$, 
$2.54(1 \mathrm{H}, \mathrm{OH}, \mathrm{brs}) 1.73(3 \mathrm{H}, \mathrm{s}) ;{ }^{13} \mathrm{C}-\mathrm{NMR}\left(125 \mathrm{MHz}, \delta, \mathrm{CDCl}_{3}\right)$ 134.2, 119.0, 92.0, 67.5, 19.5; IR (neat, $\mathrm{cm}^{-1}$ ) 3415, 3098, 2997, 2881, 2946, 1732, 1545, 1461, 1419, 1380, 1349, 1059, 944.

Scheme 4. 2-methyl-2-nitrobut-3-en-ol ( \pm )-1.

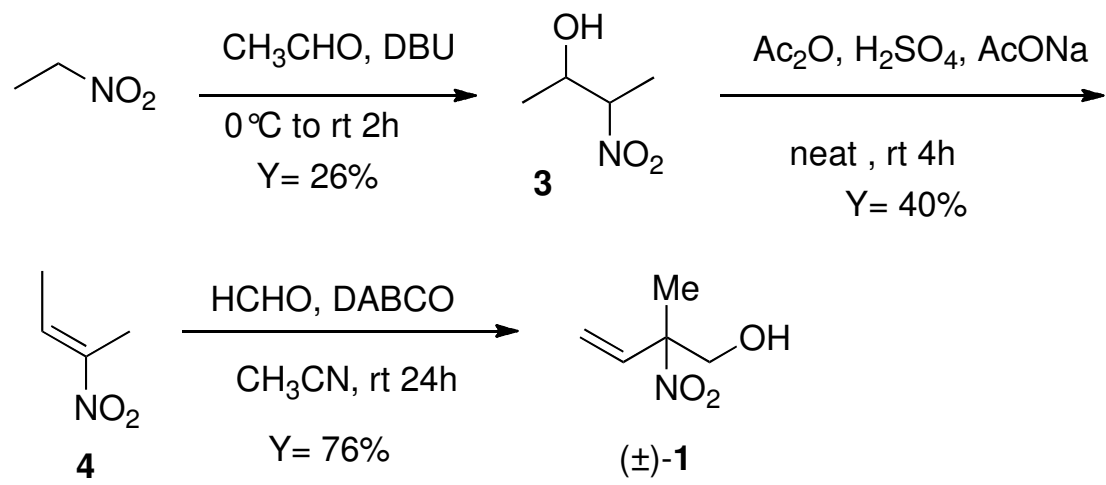

\subsection{Lipase-Catalyzed Transesterification}

To a mixture of $( \pm)-\mathbf{1}[4](5.00 \mathrm{~g}, 38.2 \mathrm{mmol})$ and vinyl acetate $(5.2 \mathrm{~mL}, 57 \mathrm{mmol})$ in $i-\mathrm{Pr}_{2} \mathrm{O}(200 \mathrm{~mL})$ was added lipase QLM powder $(2.5 \mathrm{~g})$ and the mixture was stirred at $-40{ }^{\circ} \mathrm{C}$. After stirring for $3 \mathrm{~h}$, the reaction mixture was filtered through a glass sintered filter with a Celite pad to remove the enzyme. The filtrate was evaporated and chromatographed on a silica gel flash column (hexane: ethyl acetate $=10: 1$ to 5:1) to give $(R)-2(1.59 \mathrm{~g}, 9.17 \mathrm{mmol}, 24 \%, 72 \% e e)$ and $(S)-1(3.40 \mathrm{~g}, 26.0 \mathrm{mmol}, 68 \%, 31 \% e e)$. Optical purity was determined by HPLC analysis on a chiral column. For $(R)-2$ : (CHIRALCEL OB-H, Daicel), hexane $/ i$-PrOH = 19:1, $0.5 \mathrm{~mL} / \mathrm{min} . \mathrm{R}_{\mathrm{t}}$ of $(R)-\mathbf{2}=22.8 \mathrm{~min} ; \mathrm{R}_{\mathrm{t}}$ of $(S)-\mathbf{2}=25.7$ min.; For $(S)-\mathbf{1}$ : (CHIRALCEL AD-H, Daicel), hexane $/ i-\mathrm{PrOH}=19: 1,0.5 \mathrm{~mL} / \mathrm{min} . \mathrm{R}_{\mathrm{t}}$ of $(R)-\mathbf{1}=23.9 \mathrm{~min}$; $\mathrm{R}_{\mathrm{t}}$ of $(S)-1=27.0 \mathrm{~min} .(R)-2:{ }^{1} \mathrm{H}-\mathrm{NMR}\left(500 \mathrm{MHz}, \delta, \mathrm{CDCl}_{3}\right) 6.17-6.12(1 \mathrm{H}, \mathrm{dd}, J=17.2 \mathrm{~Hz}, 6.3 \mathrm{~Hz}), 5.48$ $(1 \mathrm{H}, \mathrm{d}, J=15.3 \mathrm{~Hz}), 5.45(1 \mathrm{H}, \mathrm{d}, J=5.0 \mathrm{~Hz}), 4.58(1 \mathrm{H}, \mathrm{d}, J=11.5 \mathrm{~Hz}), 4.40(1 \mathrm{H}, \mathrm{d}, J=12.0 \mathrm{~Hz}), 2.01$ $(3 \mathrm{H}, \mathrm{s}), 1.73(3 \mathrm{H}, \mathrm{s}) ;{ }^{13} \mathrm{C}-\mathrm{NMR}\left(125 \mathrm{MHz}, \delta, \mathrm{CDCl}_{3}\right)$ 169.9, 133.6, 119.4 89.2, 67.3, 20.5, 19.5; IR (neat, $\left.\mathrm{cm}^{-1}\right) 3000,2955,2887,1753,1550,1231,1051$. The absolute configuration of $(R)-\mathbf{1}$ was confirmed by comparison with the sign of specific rotation value of $(R)$-2-amino-2-methyl-4-(4(heptyloxy)phenyl)butan-1-ol (5) [21,22] $\left([\alpha]_{\mathrm{D}}-14.4\left(\mathrm{c} 0.03, \mathrm{CHCl}_{3}\right)\right.$, lit [21] -14.0 $\left.\left(\mathrm{CHCl}_{3}\right)\right)$ which was derived from our compound $(R)-1 \quad(96 \%$ ee $)$. The results agree with the established enantio-favoritism of lipase QL-catalyzed transesterification [23].

\subsection{Synthesis of (R)-2-Amino-2-methyl-4-(4-(heptyloxy)phenyl)butan-1-ol ((R)-5) (Scheme 5)}

(R)-benzyl (2-methyl-2-nitrobut-3-en-1-yl) carbonate ((R)-6): DMAP (2.45 g, $20.06 \mathrm{mmol})$ and $i \operatorname{Pr}_{2} \mathrm{NEt}(5.1 \mathrm{~mL}, 30.0 \mathrm{mmol})$ were added to a solution of $(R)-\mathbf{1}(2.62 \mathrm{~g}, 19.98 \mathrm{mmol}, 96 \% e e)$ in $\mathrm{CH}_{2} \mathrm{Cl}_{2}(30 \mathrm{~mL})$. A solution of cbz-Cl $(3.5 \mathrm{~mL}, 24.5 \mathrm{mmol})$ in $\mathrm{CH}_{2} \mathrm{Cl}_{2}(10 \mathrm{~mL})$ was added to the solution dropwise. The mixture was stirred at room temperature for $48 \mathrm{~h}$, then poured into $1 \mathrm{M} \mathrm{HCl}$ $(20 \mathrm{~mL})$. The organic layer was separated and the water layer was extracted with $\mathrm{CH}_{2} \mathrm{Cl}_{2}(3 \times 30 \mathrm{~mL})$. The organic phases were combined and dried over $\mathrm{Na}_{2} \mathrm{SO}_{4}$. After filtration, the filtrate was concentrated and the residue was purified by flash chromatography (hexane-EtOAc 3:1) to give $(R)-6$ 
in $95 \%$ yield $(5.05 \mathrm{~g})$ Oil. The enantiomeric excess of $(R)-6$ was determined by HPLC analysis, $\mathrm{t}_{\mathrm{R}} 23.9$ $\min ((R)-6), \mathrm{t}_{\mathrm{R}} 27.0 \mathrm{~min}((S)-6)$ [CHIRALCEL AD-H $(0.46 \mathrm{~cm} \times 25 \mathrm{~cm})$ (from Daicel Chemical Ind., Ltd.) hexane $/ i-\mathrm{PrOH}, \quad 95 / 5, \quad 0.5 \mathrm{~mL} / \mathrm{min}]$ as $96 \%$ ee: $[\alpha]_{\mathrm{D}}+24.8 \quad$ (c $\left.1.67, \quad \mathrm{CHCl}_{3}\right)$; ${ }^{1} \mathrm{H}-\mathrm{NMR}\left(500 \mathrm{MHz}, \delta, \mathrm{CDCl}_{3}\right) 7.39-7.34(\mathrm{~m}, 5 \mathrm{H}), 6.11(\mathrm{dd}, J=17.4,10.9 \mathrm{~Hz}, 1 \mathrm{H}), 5.46(\mathrm{~d}, J=10.9 \mathrm{~Hz}$, 1H), $5.46(\mathrm{~d}, J=17.4 \mathrm{~Hz}, 1 \mathrm{H}), 5.16(\mathrm{~s}, 2 \mathrm{H}), 4.69$ (d, $J=11.7 \mathrm{~Hz}, 1 \mathrm{H}), 4.42(\mathrm{~d}, J=11.7 \mathrm{~Hz}, 1 \mathrm{H}), 1.75$ $(\mathrm{s}, 3 \mathrm{H}) ;{ }^{13} \mathrm{C}-\mathrm{NMR}\left(126 \mathrm{MHz}, \delta, \mathrm{CDCl}_{3}\right)$ 154.43, 134.79, 133.54, 128.87, 128.77, 128.55, 120.00, 89.18, 70.52, 70.35, 19.61; Anal. Calcd. for $\mathrm{C}_{13} \mathrm{H}_{15} \mathrm{NO}_{5}$ : C, 58.86; H, 5.70; N, 5.28. Found: C, 58.75; H, 5.77; N, 5.26.

(R,E)-benzyl (4-(4-(heptyloxy)phenyl)-2-methyl-2-nitrobut-3-en-1-yl) carbonate ((R)-8): A solution of $(R)$-6 (200.0 mg, $0.754 \mathrm{mmol})$ in dry $\mathrm{CH}_{3} \mathrm{CN}(4 \mathrm{~mL})$ was purged by $\mathrm{N}_{2}$ and $\mathrm{NaOAc}(188.0 \mathrm{mg}$, $2.292 \mathrm{mmol}$ ), $\mathrm{Pd}_{2} \mathrm{dba}_{3}$ (35.0 mg, $0.038 \mathrm{mmol}$ ) and $p-\mathrm{C}_{7} \mathrm{H}_{15} \mathrm{OC}_{6} \mathrm{H}_{4} \mathrm{~N}_{2} \mathrm{BF}_{4}$ (7) [24] (464.0 mg, $1.516 \mathrm{mmol}$ ) were added. The resulting mixture was stirred at room temperature for $48 \mathrm{~h}$. The reaction mixture was concentrated and the residue was subjected to flash chromatography (silica gel/hexane-EtOAc 12:1 then 10:1 then 6:1) to give $(R)-8$ in $63 \%$ yield $(216.0 \mathrm{mg}) .[\alpha]_{\mathrm{D}}+80.2\left(\mathrm{c} 0.46, \mathrm{CHCl}_{3}\right) .{ }^{1} \mathrm{H}-\mathrm{NMR}(500 \mathrm{MHz}$, $\left.\delta, \mathrm{CDCl}_{3}\right) 7.41-7.35(\mathrm{~m}, 5 \mathrm{H}), 7.32(\mathrm{~d}, J=8.3 \mathrm{~Hz}, 2 \mathrm{H}), 6.86(\mathrm{~d}, J=8.2 \mathrm{~Hz}, 2 \mathrm{H}), 6.70(\mathrm{~d}, J=16.0 \mathrm{~Hz}$, $1 \mathrm{H}), 6.24(\mathrm{~d}, J=16.8 \mathrm{~Hz}, 1 \mathrm{H}), 5.17(\mathrm{~s}, 2 \mathrm{H}), 4.80(\mathrm{~d}, J=11.3 \mathrm{~Hz}, 1 \mathrm{H}), 4.48(\mathrm{~d}, J=11.0 \mathrm{~Hz}, 1 \mathrm{H}), 3.96$ $(\mathrm{t}, J=6.6 \mathrm{~Hz}, 2 \mathrm{H}), 1.85(\mathrm{~s}, 3 \mathrm{H}), 1.82-1.75(\mathrm{~m}, 2 \mathrm{H}), 1.51-1.25(\mathrm{~m}, 8 \mathrm{H}), 0.90(\mathrm{t}, J=6.8 \mathrm{~Hz}, 3 \mathrm{H})$; ${ }^{13} \mathrm{C}-\mathrm{NMR}\left(126 \mathrm{MHz}, \delta, \mathrm{CDCl}_{3}\right)$ 160.10, 154.54, 134.27, 128.86, 128.78, 128.56, 128.48, 121.48, $114.83,89.30,70.90,70.30,68.16,31.80,29.22,29.08,26.00,22.63,19.89,14.12$; HRMS (ESI M+H) $m / z$ 456.2404. Calcd for $\mathrm{C}_{26} \mathrm{H}_{34} \mathrm{NO}_{5} 456.2386$.

Preparation of (R)-2-amino-2-methyl-4-(4-(heptyloxy)phenyl)butan-1-ol $((R)-5):(R)-8 \quad(199 \mathrm{mg}$, $0.0437 \mathrm{mmol})$ was dissolved in $\mathrm{MeOH}(3 \mathrm{~mL})$ and $\mathrm{Pd}-\mathrm{C}(10 \%, 20 \mathrm{mg})$ was added. The mixture was placed autoclave and stirred at room temperature under hydrogen atomosphere at $5 \mathrm{MPa}$ for $50 \mathrm{~h}$. After filtration, the filtrate was concentrated to give $(R)-5(130 \mathrm{mg})$ in $97 \%$ yield. Absolute configuration of $(R)-5$ was confirmed by comparison with the sign of specific rotation value of that reported: $\left([\alpha]_{\mathrm{D}}-14.4\left(\mathrm{c} 0.03, \mathrm{CHCl}_{3}\right)\right.$, lit [21] -14). ${ }^{1} \mathrm{H}-\mathrm{NMR}\left(500 \mathrm{MHz}, \delta, \mathrm{CD}_{3} \mathrm{OD}\right) 7.10(\mathrm{~d}, J=8.5 \mathrm{~Hz}, 2 \mathrm{H})$, $6.80(\mathrm{~d}, J=8.6 \mathrm{~Hz}, 2 \mathrm{H}), 3.92(\mathrm{t}, J=6.4 \mathrm{~Hz}, 2 \mathrm{H}), 3.39(\mathrm{~d}, J=10.6 \mathrm{~Hz}, 1 \mathrm{H}), 3.36(\mathrm{~d}, J=10.9 \mathrm{~Hz}, 1 \mathrm{H})$, 2.57 (ddd, $J=2.4,7.9,10.2 \mathrm{~Hz}, 2 \mathrm{H}), 1.81-1.69(\mathrm{~m}, 2 \mathrm{H}), 1.69-1.58(\mathrm{~m}, 2 \mathrm{H}), 1.52-1.42(\mathrm{~m}, 2 \mathrm{H})$, $1.42-1.27(\mathrm{~m}, 6 \mathrm{H}), 1.09(\mathrm{~s}, 3 \mathrm{H}), 0.91(\mathrm{t}, J=6.4 \mathrm{~Hz}, 3 \mathrm{H}) ;{ }^{13} \mathrm{C}-\mathrm{NMR}\left(126 \mathrm{MHz}, \delta, \mathrm{CD}_{3} \mathrm{OD}\right) 157.36$, $134.55,128.85,114.12$, 69.52, 67.65, 52.42, 41.22, 31.70, 29.19, 29.01, 28.94, 25.86, 22.78, 22.38, 13.15; HRMS (ESI M+H) $m / z$ 413.1642. Calcd for $\mathrm{C}_{23} \mathrm{H}_{27} \mathrm{NO}_{4} \mathrm{~S} 413.1661$. 
Scheme 5. (R)-2-amino-2-methyl-4-(4-(heptyloxy)phenyl)butan-1-ol (5).

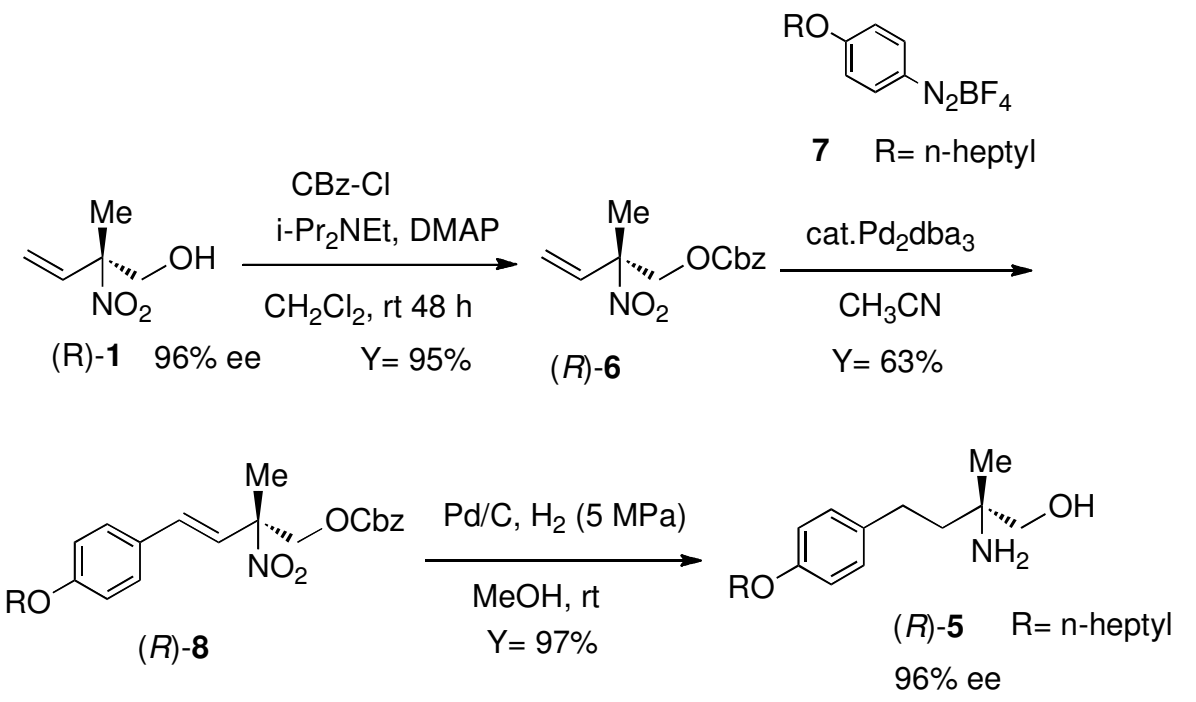

\subsection{Conversion of (R)-2 to (R)-1 by Acid Hydrolysis}

To a THF $(3.0 \mathrm{~mL})$ solution of $(R)-2(250 \mathrm{mg}, 1.44 \mathrm{mmol})$ was added $1 \mathrm{M}$ aqueous $\mathrm{HCl}$ solution $(3.0 \mathrm{~mL})$ at $\mathrm{rt}$ and the mixture was stirred for $3 \mathrm{~h}$ at $\mathrm{rt}$, and then concd. $\mathrm{HCl}(3.0 \mathrm{~mL})$ was added and the mixture was further stirred for $72 \mathrm{~h}$ at $\mathrm{rt}$. The reaction mixture was neutralized carefully with saturated sodium bicarbonate aqueous solution and extracted with dichloromethane. The combined organic layer was dried under $\mathrm{MgSO}_{4}$ and the solvent removed by evaporation. $(R)-\mathbf{1}(164 \mathrm{mg}, 1.25 \mathrm{mmol})$ was obtained in $87 \%$ yield after silica gel flash column chromatography (hexane: ethyl acetate $=10: 1$ to $5: 1)$.

\subsection{Preparation of Optically Pure (R)-2 (The Upper Route in Scheme 2)}

To a mixture of $(R)-\mathbf{1}(72 \%$ ee, $1.50 \mathrm{~g}, 8.67 \mathrm{mmol})$ and vinyl acetate $(1.0 \mathrm{~mL}, 13 \mathrm{mmol})$ in $i-\mathrm{Pr}_{2} \mathrm{O}$ $(60 \mathrm{~mL})$ was added lipase QLM powder $(0.75 \mathrm{~g})$ and the mixture was stirred at $-40{ }^{\circ} \mathrm{C}$. After being stirred for $3 \mathrm{~h}$, the reaction mixture was filtered through a glass sintered filter with a Celite pad to remove the enzyme. The filtrate was evaporated and chromatographed on a silica gel flash column (hexane: ethyl acetate $=10: 1$ to $5: 1)$ to give $(R)-\mathbf{2}(150.6 \mathrm{mg}, 0.870 \mathrm{mmol}, 10 \%,>99 \%$ ee $)$ and $(R)-\mathbf{1}$ (1.05 g, $6.07 \mathrm{mmol}, 70 \%, 69 \%$ ee $):(R)-2:[\alpha]^{26}{ }_{\mathrm{D}}-16.5\left(\mathrm{c} 0.57, \mathrm{CDCl}_{3}\right),>99 \%$ ee.

\subsection{Preparation of (S)-1 with High Optical Purity (Bottom Route in Scheme 3)}

To a mixture of $(S)-\mathbf{1}(31 \%$ ee, $3.40 \mathrm{~g}, 25.9 \mathrm{mmol})$ and vinyl acetate $(3.5 \mathrm{~mL}, 39 \mathrm{mmol})$ in $i$ - $\operatorname{Pr}_{2} \mathrm{O}$ $(120 \mathrm{~mL})$ of was added lipase QLM powder $(1.70 \mathrm{~g})$ and the mixture was stirred at $-40{ }^{\circ} \mathrm{C}$. After being stirred for $24 \mathrm{~h}$, the reaction mixture was filtered through a glass sintered filter with a Celite pad to remove the enzyme. The filtrate was evaporated and chromatographed on a silica gel flash column (hexane: ethyl acetate $=10: 1$ to 5:1) to give $(S)-2(3.41 \mathrm{~g}, 19.6 \mathrm{mmol}, 76 \%, 18 \%$ ee $)$ and $(S)-1(305.5 \mathrm{mg}$, 2.33 mmol, 9\%, 94\% ee): $(S)-\mathbf{1}:[\alpha]^{26}{ }_{\mathrm{D}}+76.8\left(\mathrm{c} 0.26, \mathrm{CDCl}_{3}\right), 94 \%$ ee. $(S)-\mathbf{2}$ was converted to $(S)-\mathbf{1}$ (18\% ee) by acid hydrolysis and the resulting $(S)-\mathbf{1}(2.34 \mathrm{~g})$ was combined with $(R)-\mathbf{1}(1.05 \mathrm{~g})$, which 
was obtained by the upper route in Scheme 2, to prepare low \% ee substrate alcohol 1 (3.39 g, 7.4\% ee $(R))$, then used for the next cycle of the lipase-catalyzed reaction.

\section{Conclusions}

In summary, we established a convenient protocol to prepare both enantiomers of 2-methyl-2nitrobut-3-en-1-ol (1) with over 94\% ee using lipase-catalyzed transesterification under low temperature reaction conditions. It was possible to apply the reaction protocol to the multi gram scale preparation and we succeeded in preparing the desired compounds easily. Synthetic application of a medicinal compound using optically active $\mathbf{1}$ is now ongoing in our laboratory.

\section{Acknowledgment}

The present work was supported by a Grant-in-Aid for Environmental Research from Tottori Prefecture, Japan.

\section{Conflict of Interest}

The authors declare no conflict of interest.

\section{References and Notes}

1. Wong, C.-H.; Whitesides, G.M. Enzymes in Synthetic Organic Chemistry; Elsevier Science Ltd: Pergamon, Oxford, UK, 1994.

2. Faber, K. Biotransformations in Organic Chemistry, 6th ed.; Springer-Verlag Berlin: Heidelberg, Germany, 2011.

3. Matsuda, T., Ed. Future Directions in Biocatalysis; Elsevier: Amsterdam, The Netherlands, 2007.

4. Ono, N.; Hamamoto, I.; Kamimura, A.; Kaji, A.; Tamura, R. Reaction of carbanions derived from alpha,BETA-unsaturated nitrocompounds with electrophiles to give alpha,beta-substituted products. Synthesis 1987, 3, 258-260.

5. Itoh, T. Future Directions in Biocatalysis; Matsuda, T., Ed.; Elsevier: Amsterdam, The Netherlands, 2007; Chapter 1, pp. 3-20.

6. Lalonde, J.J.; Bergbreiter, D.E.; Wong, C.-H. Enzymatic kinetic resolution of $\alpha$-nitro $\alpha$-methyl carboxylic acids. J. Org. Chem. 1988, 53, 2323-2327.

7. Im, D.S.; Cheong, C.S.; Lee, S.H. Lipase-catalyzed remote kinetic resolution of quaternary carbon-containing alcohols and determination of their absolute configuration. Bull. Korean Chem. Soc. 2003, 24, 1269-1275.

8. Im, D.S.; Cheong, C.S.; Lee, S.H. Lipase-catalyzed remote kinetic resolution of arylic nitriles with adjacent quaternary chiral center and the determination of their absolute configuration. J. Mol. Catal. B: Enzym. 2003, 26, 131-143.

9. Angoli, M.; Barilli, A.; Lesma, G.; Passarella, D.; Riva, S.; Silvani, A.; Danieli, B. Remote stereocenter discrimination in the enzymatic resolution of piperidine-2-ethanol. Short enantioselective synthesis of sedamine and allosedamine. J. Org. Chem. 2003, 68, 9525-9527. 
10. Irimescu, R.; Saito, T.; Kato, K. Enzymatic kinetic resolution of primary alcohols by direct esterification in solvent-free system. J. Mol. Catal. B: Enzym. 2004, 27, 69-73.

11. Solares, L.F.; Brieva, R.; Quiro, M.; Llorente, I.; Bayodb, M; Gotor, V. Enzymatic resolution of a quaternary stereogenic centre as the key step in the synthesis of $(S)-(+)$-citalopram. Tetrahedron Asymmetry 2004, 15, 341-345.

12. Recuero, V.; Ferrero, M.; Gotor-Fernández, V.; Brieva, R.; Gotor, V. Enzymatic resolution of hindered cyanohydrins, key precursors of muscarinic receptor antagonists. Tetrahedron Asymmetry 2007, 18, 994-1002.

13. Felluga, F.; Ghelfi, F.; Pitacco, G.; Roncaglia, F.; Valentin, E.; Venneri, C.D. Esterase-mediated synthesis of optically active GABA analogues containing a stereogenic all-carbon quaternary carbon atom. Tetrahedron Asymmetry 2010, 21, 2183-2191.

14. Sakai, T. Future Directions in Biocatalysis; Matsuda, T., Ed.; Elsevier: Amsterdam, The Netherlands, 2007; Chapter 2, pp. 21-50.

15. Sakai, T.; Kawabata, I.; Kishimoto, T.; Ema, T.; Utaka, M. Enhancement of the enantioselectivity in lipase-catalyzed kinetic resolutions of 3-phenyl-2 $\mathrm{H}$-azirine-2-methanol by lowering the temperature to $-40{ }^{\circ} \mathrm{C}$. J. Org. Chem. 1997, 62, 4906-4907.

16. Sakai, T.; Kishimoto, I.; Ema, T.; Utaka, M. Low-temperature method for enhancement of enantioselectivity in the lipase-catalyzed kinetic resolutions of solketal and some chiral alcohols. Tetrahedron Lett. 1998, 39, 7881-7884.

17. Chen, C.-S.; Fujimoto, Y.; Girdaukas, G.; Sih, C.J. Quantitative analyses of biochemical kinetic resolutions of enantiomers. J. Am. Chem. Soc. 1982, 104, 7294-7298.

18. Jones, J.B. Applications of Biochemical Systems in Organic Chemistry; Jones, J.B., Shi, C.J., Perlman, D., Eds.; Wiley: New York, NY, USA, 1976; pp. 1-46.

19. Ema, T.; Kobayashi, J.; Maeno, S.; Sakai, T.; Utaka, M. Origin of the enantioselectivity of lipases explained by a stereo-sensing mechanism operative at the transition state. Bull. Chem. Soc. Jpn. 1998, 71, 443-453.

20. Ema, T. Rational strategies for highly enantioselective lipase-catalyzed kinetic resolutions of very bulky chiral compounds: Substrate design and high-temperature biocatalysis. Tetrahedron Asymmetry 2004, 15, 2765-2720.

21. Hinterding, K.; Albert, R.; Cottens, S. First asymmetric synthesis of chiral analogues of the novel immunosuppressant FTY720. Tetrahedron Lett. 2002, 43, 8095-8097.

22. Nakamura, T.; Tsuji, T.; Iio, Y.; Miyazaki, S.; Takemoto, T.; Nishi, T. Asymmetric synthesis of a,a-disubstituted a-amino alcohol derivatives. Tetrahedron Asymmetry 2006, 17, 2781-2792.

23. Itoh, T.; Ishida, N.; Mitsukura, K.; Hayase, S.; Ohashi, K. Synthesis of optically active gem-difluorocyclopropanes through a chemo-enzymatic reaction strategy. J. Fluorine Chem. 2004, 125, 775-783.

24. Felpin, F. X.; Coste, J.; Zakri, C.; Fouquet, E. Preparation of 2-quinolones by sequential Heck Reduction-Cyclization (HRC) reactions by using a multitask palladium catalyst. Chem. Eur. J. 2009, 15, 7238-7245. 
Sample availability: not available

(C) 2011 by the authors; licensee MDPI, Basel, Switzerland. This article is an open access article distributed under the terms and conditions of the Creative Commons Attribution license (http://creativecommons.org/licenses/by/3.0/). 